\title{
Aktivitas Public Relations Angkasa Pura II Dalam Menangani Pemberitaan Negatif Terminal 3 Bandara Soekarno-Hatta
}

\author{
Sarah Jessica ${ }^{1}$ dan Ayub Ilfandi ${ }^{2}$ \\ ${ }^{1,2}$ Universitas Telkom
}

\begin{abstract}
ABSTRAK
Salah satu bandara yang memiliki aktivitas cukup padat di Indonesia adalah Bandara Internasional Soekarno - Hatta. PT Angkasa Pura II sebagai pengelola Bandara Internasional Soekarno-Hatta melakukan pengembangan Terminal 3 untuk menangani lonjakan penumpang yang terjadi tiap periode libur panjang. Namun, beberapa saat setelah beroperasi, masyarakat dan media kerap melaporkan beberapa keluhan terhadap fasilitas sarana dan prasarana di Terminal 3 seperti listrik mati, banjir, dan kritik dari publik figur Indonesia. Pelaporan dari masyarakat dan media menuntut adanya tindakan nyata dari seorang praktisi public relations PT Angkasa Pura II. Metode yang digunakan pada penelitian ini yaitu metode deskriptif kualitatif dengan menggunakan teknik in-depth interview, observasi, dan dokumentasi. Tujuan dari penelitian ini yaitu untuk mengetahui bagaimana aktivitas public relations PT Angkasa Pura II dalam menangani pemberitaan negatif pada awal pembukaan Terminal 3 Bandara Internasional Soekarno-Hatta. Berdasarkan hasil penelitian dan pembahasan, diketahui bahwa PT Angkasa Pura II telah menjalankan aktivitas public relations dengan 5 tahapan krisis untuk mengetahui daur hidup krisis diantaranya (1) tahap pre-crisis, (2) tahap warning, (3) tahap acute crisis, (4) tahap clean-up, dan (5) tahap post-crisis. Selain itu public relations PT Angkasa Pura II juga melakukan tindakan korektif sebagai upaya mengelola krisis diantaranya (1) identifikasi krisis, (2) analisa krisis, (3) isolasi krisis, (4) pilihan strategi, dan (5) program pengendalian. Dimana dengan melakukan tindakan terhadap suatu krisis berarti PT Angkasa Pura II telah bertanggung jawab terhadap stakeholdernya sekaligus untuk melihat sejauh mana perkembangan krisis itu dalam masyarakat.
\end{abstract}

Kata-kata Kunci: Public relations; aktivitas public relations; krisis; tahapan krisis; pengelolaan krisis

\section{The Activity Of Public Relations Of Angkasa Pura II In Handling Negative News Terminal 3 Soekarno - Hatta Airport}

\begin{abstract}
One of the busiest airport in Indonesia is the Soekarno - Hatta International Airport. PT Angkasa Pura II as the developer of the Soekarno - Hatta International Airport develops Terminal 3 to handle the surge of passengers who happen in every long holiday period. However, sometimes after the operation, the public and the media often reported several complaints against facilities and infrastructure facilities in Terminal 3 as power of failure, flood, and criticism of public figures Indonesia. Reporting from the public and media demands a real action of a public relations practitioner of PT Angkasa Pura II.The method used in this research is descriptive qualitative method by using the technique of in-depth interviews, observation, and documentation. The objective of this study is to determine how the public relations activities of PT Angkasa Pura II in addressing the negative news in the beginning of the opening of Terminal 3 Soekarno - Hatta. Based on the results of research and discussions, it is known that PT Angkasa Pura II has been running a public relations activity with 5 stages of crisis to know the life cycle of crisis including: (1) the stage of precrisis, (2) phase warning, (3) the stage of acute crisis, (4) clean-up stage, and (5) post-crisis phase. Besides public relations, PT Angkasa Pura II also performs corrective actions as an attempt to manage the crisis including: (1) identification of the crisis, (2) analysis of the crisis, (3) isolation of the crisis, (4) the choice of strategy, and (5) control program. Taking action against a crisis means PT Angkasa Pura II has been responsible for its stakeholders as well as to see the extent of the crisis in society.
\end{abstract}

Keywords: Public relations; public relations activities; crisis; stages of crisis; crisis management

Korespondensi: Sarah Jessica, S.I.Kom. Program Studi Ilmu Komunikasi, Fakultas Komunikasi dan Bisnis, Universitas Telkom, Jl. Telekomunikasi Terusan Buah Batu, Bandung 40257. Email: sarjessca@gmail.com 


\section{PENDAHULUAN}

Bandara atau bandar udara merupakan fasilitas untuk pesawat terbang dan helicopter dapat lepas landas dan mendarat. Fungsi bandara itu sendiri adalah sebagai tempat penumpang atau barang untuk naik atau turun dari pesawat terbang. Bagi sebuah Negara bandara menjadi aspek penting karena dapat menghubungkan antar wilayah, antar pulau, dan antar negara. Indonesia sebagai negara kepulauan memerlukan alat transportasi pesawat udara sekaligus bandar udara sebagai akomodasi untuk menyamaratakan pertumbuhan ekonomi di wilayah-wilayah yang bukan kota metropolitan, mempercepat arus lalu lintas penumpang, kargo dan pelayanan di setiap pelosok Indonesia. Selain itu, bandar udara juga merupakan infrastruktur yang penting untuk sektor pariwisata. Tidak hanya sektor pariwisata, bandar udara (bandara) yang tadinya hanya menjadi tempat sekedar menunggu bagi para penumpang yang akan berangkat atau datang dengan pesawat udara sekarang sebagian masyarakat dapat membuka peluang bisnis atau usaha karena tersedianya ruang commercial (commercial space) untuk membuka gerai.

Salah satu bandara tersibuk di Indonesia adalah Bandara Internasional SoekarnoHatta. Bandara Internasional Soekarno-
Hatta menduduki peringkat ke-8 di Asia sebagai bandara tersibuk. Berdasarkan Airport Council International (ACI) dengan menghitung jumlah pergerakan penumpang yang mencapai 54 juta sepanjang tahun 2015 . Kesibukan bandara yang paling dekat dengan pusat ekonomi Indonesia ini disumbang oleh lonjakan penumpang yang terjadi tiap periode libur panjang. Sedangkan, daya tampung keseluruhan terminal keberangkatan Bandara Internasional Soekarno-Hatta hanya sekitar 22 juta penumpang. PT Angkasa Pura II sebagai perusahaan pengelola Bandara Internasional Soekarno-Hatta mengembangkan Terminal 3 (T3) untuk menanggulangi hal tersebut. Pembangunan T3 dimulai sejak Agustus 2012.

Pengembangan T3 diestimasikan daya tampung penumpang total di T3 akan mencapai 25 juta penumpang per tahun. Terminal 3 baru ini akan mengusung konsep Art \& Culture yang dimana akan dipasang beberapa lukisan dan patung Garuda. Selain itu, Terminal 3 akan menggunakan kecanggihan teknologi modern. Seiring akan dioperasikannya Terminal 3 Bandara Internasional Soekarno-Hatta, PT Angkasa Pura II (Persero) telah melakukan beberapa kegiatan sosialisasi T3 yang melibatkan masyarakat khususnya para netizen. Kegiatan sosialisasi tersebut diantaranya: kunjungan komunitas iphonesia, kunjungan 
Alvin Lie bersama detik.com, kunjungan blogger dan traveller, kunjungan Jakarta Photo Club \& Majalah Venue, dan Terminal 3 Fashion Show (PT Angkasa Pura II with Liputan 6).

Pengoperasian Terminal 3 Bandara Internasional Soekarno-Hatta pada awalnya direncanakan beroperasi pada tanggal 15 Juni 2016 namun diundur menjadi tanggal 20 Juni 2016 karena belum memenuhi persyaratan terkait standar keselamatan, keamanan, dan pelayanan penerbangan sipil. Menurut Yudhi Sari selaku Direktur Bandar Udara Kementerian Perhubungan yang dilansir dephub.go.id (2016) hasil tersebut didapat setelah tim dari Kementrian Perhubungan melakukan verifikasi dan uji coba kehandalan peralatan keselamatan, keamanan, serta pelayanan di Terminal 3. Hal penting yang masih belum memenuhi standar yaitu pada sistem kelistrikan terminal, hasil uji coba pada sistem listrik cadangan menunjukan empat unit genset yang tersedia belum bisa menjangkau peralatan - peralatan di terminal. Yudhi Sari mengatakan pada saat menggunakan jaringan utama PLN, sistem berjalan dengan baik. Namun, saat uji coba menggunakan genset sistem tidak berjalan. Ini menyebabkan berbagai fasilitas di terminal tidak berfungsi. Maka dari itu, Terminal 3 baru dapat beroperasi pada tanggal 9 Agustus 2016.

Beberapa saat setelah beroperasi, media dan masyarakat kerap melaporkan beberapa keluhan terhadap fasilitas sarana dan prasarana di Terminal 3 seperti listrik mati, banjir, dan kritik dari publik figur Indonesia. Pelaporan dari masyarakat dan media menuntut adanya tindakan nyata dari seorang praktisi public relations.

Aktivitas PR memiliki peranan penting untuk menangani krisis tersebut. Jika tidak langsung ditanggapi dengan tepat, segala bentuk pelaporan tersebut akan membentuk opini publik yang tidak sesuai dengan fakta di lapangan. Hal tersebut akan berdampak negatif bagi citra perusahaan. Oleh karena itu, peneliti akan meninjau lebih lanjut mengenai aktivitas public relations PT Angkasa Pura II dalam menangani pemberitaan negatif pada awal pembukaan Terminal 3 Bandara Internasional Soekarno-Hatta.

\section{METODE PENELITIAN}

Metode yang digunakan peneliti dalam melakukan penelitian ini yaitu metode penelitian deskriptif, sementara kualitatif merupakan pendekatan untuk menentukan jenis penelitian. Sesuai dengan jenis penelitian ini, peneliti berusaha memahami makna dari suatu fenomena berdasarkan pandangan para informan. Penelitian kualitatif adalah penelitian yang dimaksudkan untuk memahami fenomena tentang apa yang dialami oleh subjek penelitian, secara holistik, dan dengan cara deskripsi dalam 
bentuk kata-kata dan bahasa pada suatu konteks khusus yang alamiah dan dengan memanfaatkan metode alamiah (Moleong dalam Iqbal, 2014).

Peneliti menggunakan paradigma postpositvis karena memandang aktivitas public relations yang dilakukan oleh divisi public relations PT Angkasa Pura II dalam menangani pemberitaan negatif pada awal pembukaan Terminal 3 Bandara Internasional SoekarnoHatta sebagai kausalitas yang memiliki sebabakibat dan probabilitas. Namun, tidak hanya dipandang sebagai kontruksi realitas melainkan dapat dilihat dari berbagai sudut pandang.

Subjek penelitian ini adalah divisi public relations PT Angkasa Pura II (Persero). Divisi public relations PT Angkasa Pura II (Persero) merupakan divisi dibawah unit Head Corporate Secretary \& Legal dipilih peneliti sebagai subjek karena divisi public relations tersebut bertanggung jawab terhadap pemberitaan Terminal 3 Bandara Internasional SoekarnoHatta. Objek dalam penelitian ini adalah aktivitas public relations yang dilakukan oleh divisi public relations PT Angkasa Pura II dalam menangani pemberitaan negatif pada awal pembukaan Terminal 3 Bandara Internasional Soekarno-Hatta.

Waktu yang digunakan dalam penelitian ini selama bulan Agustus 2016 - Januari 2017. Lokasi penelitian bertempat di kantor PT Angkasa Pura II (Persero) Bandara Internasional
Soekarno-Hatta Gedung 600, Tangerang Banten.

Teknik pengumpulan data adalah bagian instrumen pengumpulan data yang menentukan berhasil atau tidak suatu penelitian. Tanpa mengetahui teknik pengumpulan data, maka peneliti tidak akan mendapatkan data yang semestinya dan yang telah ditetapkan (Sugiyono, 2013: 62).

Dalam penelitian ini, untuk memperoleh data peneliti menggunakan sumber data. Sumber data adalah salah satu yang paling vital dalam penelitian. Jika terjadi kesalahan dalam menggunakan atau memahami sumber data, maka data yang diperoleh bisa tidak sesuai dari yang diharapkan (Bungin, 2013: 129). Terdapat dua jenis sumber data yang biasanya digunakan yaitu: Data primer adalah data yang didapatkan secara langsung oleh peneliti melalui informan penelitian atau sumber pertama di lapangan.

Peneliti mendapatkan data primer dengan cara observasi dan wawancara. Observasi atau pengamatan adalah kegiatan untuk menghimpun data penelitian, data penelitian tersebut dapat diamati oleh peneliti. Biasanya dalam penelitian kualitatif harus mempersiapkan materi pengamatan terlebih dahulu dan instrumen yang akan digunakan (Bungin, 2013: 143). Di lapangan banyak data yang akan ditemui oleh peneliti dan banyak juga yang tidak diperlukan karena tidak terkait atau tidak menjawab 
rumusan masalah penelitian (Mukhtar, 2013:

111). Maka dari itu, peneliti memerlukan materi sebagai panduan penelitian observasi agar lebih memudahkan peneliti untuk menemukan sasarannya dan lebih mendalami subjek dan situasi sosial yang diteliti. Proses memperoleh keterangan untuk tujuan penelitian dengan cara tanya jawab sambil bertatap muka antara pewawancara dengan responden atau orang yang diwawancarai. Wawancara yang dilakukan dalam penelitian ini dengan menggunakan daftar pertanyaan yang telah dipersiapkan oleh peneliti sesuai dengan rumusan dan pertanyaan penelitian yang dijawab melalui proses wawancara (Bungin, 2013: 133).

Data sekunder merupakan data yang diperoleh dari sumber kedua atau sumber sekunder. Data sekunder bisa didapatkan melalui studi kepustakaan, buku, jurnal ilmiah, literatur, dokumentasi dan arsip kantor PT Angkasa Pura II. Peneliti mendapatkan data sekunder dengan cara data dokumentasi. Metode pengumpulan data yang sebagian besar fakta dan data tersimpan dalam bahan yang berbentuk dokumentasi. Sebagian besar data berbentuk surat, catatan, harian, arsip, foto, video, hasil rapat, cinderamata, jurnal kegiatan, dan sebagainya. Data pendukung ini merupakan satu kesatuan dengan data observasi dan wawancara yang sebelumnya telah dilakukan. Sehingga saat peneliti menyusun laporan penelitiannya dalam proses triangulasi, ketiga data yang telah dihimpun melalui observasi, wawancara dan dokumentasi, ketiga data harus dapat saling menguatkan antara yang satu dengan lainnya. Dengan demikian, dapat ditemukan dan ditarik makna dari setiap informasi atau data yang ditemukan di lapangan (Mukhtar, 2013: 119).

Analisis data yang dilakukan dalam penelitian ini menggunakan teori menurut Miles dan Huberman (1984) (dalam Sugiyono, 2014: 91) mengemukakan bahwa aktivitas dalam analisis data kualitatif dilakukan secara interaktif dan berlangsung secara terus menerus sampai tuntas, sehingga datanya sudah jenuh. Empat aktivitas dalam analisis data yang dilakukan dalam pendekatan ini, yaitu pengumpulan data, data reduction, data display, dan conclusion drawing/verification.

Teori yang digunakan pada penelitian ini: Aktivitas public relations. Aktivitas public relations adalah mendukung tujuan umum dari suatu manajemen perusahaan serta menciptakan dan mempertahankan identitas dan citra perusahaan (Ruslan, 2007: 94) yaitu: 1). Menciptakan identitas dan citra perusahaan (building corporate identities and image, public relations berupaya menciptakan citra yang positif dengan berbagai aktivitas atau kepedulian sosial terhadap masyarakat di sekitarnya untuk menumbuhkan pemahaman, pengertian, dan kesadaran (awareness) dan pengetahuan 
(knowledge) publik terhadap perusahaan yang diwakilinya. 2). Mengatasi suatu krisis yang terjadi public relations dalam mengatasi sebuah krisis dengan membentuk manajemen khusus untuk menghadapi kemungkinan terjadinya suatu krisis (Management of $P R$ crisis) dimulai dari bagaimana menangani keluhan (handling of complaint), protes dan sebagainya. Kemudian public relations membentuk tim untuk menghadapi krisis, dari krisis kepercayaan (crisis of confidence), krisis manajemen (perusahaan yang tengah mengalami suatu krisis), atau proyek yang menimbulkan kecelakaan sehingga konsumen atau masyarakatnya menjadi korban.

Selain itu, menurut Frank Jefkins dalam bukunya Public relations (2004: 31-32) seorang public relations memiliki tugas khusus yang biasa dilakukan yaitu sebagai berikut: 1). Menciptakan dan memelihara suatu citra yang baik dan tepat atas perusahaan atau organisasinya, baik yang berhubungan dengan kebijakan perusahaan atau organisasinya serta produk, jasa, maupun dengan pegawainya. 2). Mengawasi pendapat eksternal mengenai segala sesuatu yang berkaitan dengan citra, kegiatan, reputasi maupun kepentingankepentingan organisasinya dan menyampaikan semua informasi yang penting langsung kepada pihak manajemen untuk segera ditanggapi atau ditindaklanjuti. 3). Memberi nasihat atau masukan kepada pihak manajemen mengenai berbagai masalah komunikasi yang penting, seperti teknis untuk mengatasinya. 4). Menyediakan berbagai informasi kepada khalayak perihal kebijakan organisasi, kegiatan, produk jasa, dan pegawainya selengkap mungkin demi menciptakan suatu pengetahuan yang maksimal dalam rangka menjangkau pengertian khalayak.

Kata krisis berasal dari bahasa Yunani krisis (kpion), yang berarti “keputusan”. Ketika krisis terjadi, perusahaan harus memutuskan apa yang harus dilakukan. Bergerak ke kiri, atau bergeser ke kanan, ke bawah atau ke atas, bertarung atau melarikan diri (Nova, 2009: 54).

Selain itu, definisi krisis yang diungkapkan oleh Rusady Ruslan (2007: 97) adalah "The crisis is turning point of better or worse. Time of acute danger or difficulty". Artinya suatu krisis yang terjadi merupakan titik penentu untuk menghadapi tahap selanjutnya, apakah akan pulih kembali atau sebaliknya menghadapi resiko yang buruk dan mengalami masa gawat pada suatu perusahaan dan produk, barang atau jasa, tengah menghadapi suatu kisis kepercayaan dan citra (crisis of confidence and lost off image). Sedangkan menurut Fisher (2001) krisis merupakan puncak konflik, ketika ketegangan dan kekerasan terjadi hebat diantara kedua belah pihak (Suherli, 2014).

Krisis public relations adalah peristiwa, 
rumor, atau informasi yang membawa pengaruh buruk terhadap reputasi, citra, dan kredibilitas perusahaan. Kebanyakan perusahaan berpikir krisis PR hanya menyerang perusahaan besar, padahal krisis bisa menyerang siapa saja, baik individu, organisasi, maupun perusahaan, kapan dan di mana saja (Nova, 2009: 54).

Praktisi public relations memiliki peranan penting untuk menangani krisis karena mengingat masa krisis dapat berdampak negatif terhadap citra perusahaan. Dapat dikatakan public relations adalah fungsi manajemen yang strategis. Agar fungsi strategis tersebut berjalan dengan baik, sebaiknya posisi public relations berada dibawah pimpinan puncak agar memiliki wewenang yang memungkinkan fungsinya dapat dijalankan secara efektif mengingat dampak negatif dan kerugian besar bahkan citra perusahaan akan terganggu ketika terjadinya krisis. Firsan Nova dalam bukunya Crisis Public Relations (Nova, 2009: 95) memaparkan lima tahapan dalam siklus hidup krisis yang harus dikenali dan dipahami adalah sebagai berikut:

Tahap pre-crisis (sebelum krisis), kondisi sebelum sebuah krisis muncul disebut precrisis. Benih krisis sudah ada sehingga jika muncul suatu kesalahan yang kecil saja, krisis dapat terjadi. Benih mulai tumbuh pada tahap ini biasanya tidak diperhatikan karena beberapa aspek dalam perusahaan memang penuh risiko. Selain itu, perusahaan tidak mempunyai perencanaan menghadapi krisis.

Tahap paling penting dalam daur hidup krisis. Di dalamnya, suatu masalah untuk pertama kalinya dikenali, dapat dipecahkan dan diakhiri selamanya, atau dibiarkan berkembang menuju kepada kerusakan yang menyeluruh. Krisis dapat dengan mudah muncul pada tahap ini karena ketakutan menghadapi 'badai' atau 'masalah' dan menganggapnya tidak ada. Reaksi yang umum terjadi pada tahap ini adalah kaget atau menyangkal dan pura-pura merasa aman.

Tahap ini krisis mulai terbentuk dan media juga publik mulai mengetahui adanya masalah. Dalam tahap ini, perusahaan tidak dapat berdiam diri karena sudah mulai menimbulkan kerugian. Saat inilah berbagai dokumen dan modul untuk menghadapi krisis harus dikeluarkan dan digunakan. Di saat seperti ini juga dapat diketahui apakah para staf telah dibekali pengetahuan mengenai manajemen krisis atau tidak. Jika tidak, maka sudah terlambat bagi manajemen untuk memulainya dan menyelesaikan masalahnya.

Tahap clean-up (pembersihan): Saat masalah melewati tahap warning tanpa diselesaikan maka kerusakan perusahaan mulai timbul. Inilah waktunya untuk memulihkan perusahaan dari kerugian dan/atau setidaknya menyelamatkan apa saja yang tersisa, baik sisa produk (jika dapat diaplikasikan), reputasi, citra 
perusahaan, kinerja, dan lini produksi.

Tahap post-crisis (sesudah krisis): Inilah tahap yang telah disebutkan sebelumnya, yakni perusahaan seharusnya bereaksi saat suatu krisis muncul ke tahap warning. Jika sejak awal tidak dihentikan, krisis akan terjadi. Jika perusahaan memenangkan kembali kepercayaan publik dan dapat beroperasi kembali dengan normal, maka secara formal dapat dikatakan krisis telah berakhir.

Ketika krisis terjadi, maka tugas pertama para anggota manajemen krisis adalah mengidentifikasi dan menentukan langkahlangkah apa saja yang harus dilakukan. Menurut Kasali (2000: 231-234) adapun langkahlangkah yang perlu dilakukan dalam mengelola krisis adalah sebagai berikut: 1). Identifikasi krisis. Public relations perlu melakukan penelitian untuk dapat mengidentifikasi suatu krisis. Bila krisis terjadi dengan cepat, maka penelitian harus dilakukan secara informal dan kilat, harus diusahakan kesimpulan atas identifikasi krisis yang terjadi ditarik pada hari yang sama saat data dikumpulkan. Oleh sebab itulah dibutuhkan praktisi humas yang cakap dan peka dalam mengumpulkan data yang diperlukan. 2). Analisa krisis sebelum melakukan komunikasi. Public relations officer harus melakukan analisis dari data yang telah diperoleh, maka tugas public relations selanjutnya adalah menganalisis krisis yang dilakukan baik secara parsial maupun integral sampai analisis integral yang kait mengait. Dalam tahap ini dibutuhkan kemampuan membaca permasalahan yang baik. Beberapa pertanyaan yang diajukan untuk menetapkan penanggulangan krisis, yakni: a). Apa penyebab terjadinya krisis itu -What, b). Kenapa krisis itu bisa terjadi -Why, c). Di mana dan kapan krisis tersebut terjadi -Where and When, d). Sejauh mana krisis tersebut berkembang-How Far, e). Bagaimana krisis itu terjadi -How, f). Siapasiapa yang mampu mengatasi krisis tersebut, perlu dibentuk tim penanggulangan krisis - Who. 3). Isolasi krisis layaknya seperti penyakit dan untuk mencegah krisis menyebar luas maka krisis harus diisolasi, dikarantinakan sebelum tindakan serius dilakukan, 4). Pilihan strategi sebelum mengambil langkah pengendalian krisis, perusahaan perlu melakukan penetapan strategi yang akan diambil.

Ada tiga strategi yang dapat dilakukan untuk menangani krisis yaitu: a). defensive strategy (strategi defensif) dengan langkahlangkah sebagai berikut: mengulur waktu, tidak melakukan apa-apa, membentengi diri dengan kuat, b). adaptive strategy (strategi adaptif) dengan langkah-langkah yang mencakup halhal yang lebih luas sebagai berikut: mengubah kebijakan, modifikasi operasional, kompromi, meluruskan citra, c). dynamic strategy (strategi dinamis), strategi ini sudah bersifat agak 
makro dan dapat mengakibatkan berubahnya karakter perusahaan. Pilihannya adalah: merger dan akuisisi, investasi baru, menjual saham, meluncurkan produk baru/ menarik peredaran produk lama, melempar isu baru untuk mengalihkan perhatian.

Program pengendalian merupakan langkah penerapan yang dilakukan menuju strategi generik yang dirumuskan. Umumnya startegi generik dapat dirumuskan jauh hari sebelum krisis muncul, yakni sebagai panduan (guidance) agar para eksekutif dapat mengambil langkah yang pasti dengan strategi generik, program pengendalian biasanya disusun di lapangan ketika krisis muncul. Impelementasi pengendalian diterapkan pada: Perusahaan (beserta cabang), industri (gabungan usaha sejenis), komunitas, divisi-divisi perusahaan.

\section{HASIL DAN PEMBAHASAN}

Tahap pre-crisis adalah kondisi sebelum sebuah krisis muncul. Benih krisis sudah ada sehingga jika muncul suatu kesalahan yang kecil saja, krisis dapat terjadi. Benih mulai tumbuh pada tahap ini biasanya tidak diperhatikan karena beberapa aspek dalam perusahaan memang penuh risiko. Selain itu, perusahaan tidak mempunyai perencanaan menghadapi krisis (Nova, 2009: 95). Senada dengan Yogi (2016) bahwa krisis citra sebuah perusahaan adalah krisis citra berkembang jauh lebih besar daripada kenyataan yang terjadi di lapangan.

Mengacu pada pengertian tersebut, hasil penelitian yang didapatkan dari wawancara dengan PR Senior Officer dan PR Junior Officer hal yang dilakukan PT Angkasa Pura II sebelum krisis muncul yaitu melakukan press conference bersama Garuda Indonesia untuk membahas operasional sekaligus melakukan simulasi pengoperasian Terminal 3 Bandara Internasional Soekarno-Hatta. Terlihat bahwa krisis yang terjadi terhadap PT Angkasa Pura II datang secara tiba-tiba, tidak terduga dan tidak diharapkan. Pihak perusahaan tidak memiliki waktu untuk melakukan riset terlebih dahulu maupun perencanaan.

Berdasarkan hasil analisis yang peneliti lakukan dikaitkan dengan teori konsep tahapan krisis maka benih krisis muncul secara tibatiba yang terjadi pada tanggal 9 Agustus 2016 bertepatan dengan soft launching Terminal 3 Bandara Soekarno Hatta. Dan memang benar seperti teori itu ungkapkan bahwa karena krisis yang tiba-tiba sehingga perusahan tidak mempunyai perencanaan dalam menghadapinya.

Menurut Nova (2009: 96) tahap warning (peringatan) merupakan tahap paling penting dalam daur krisis. Di dalamnya, suatu masalah untuk pertama kalinya dikenali, dapat dipecahkan dan diakhiri selamanya, atau dibiarkan berkembang menuju kepada 
kerusakan yang menyeluruh. Krisis dapat dengan mudah muncul pada tahap ini karena ketakutan menghadapi 'badai' atau 'masalah' dan menganggapnya tidak ada. Reaksi yang umum terjadi pada tahap ini adalah kaget atau menyangkal dan pura-pura merasa aman.

Sehubungan dengan hasil penelitian, bentuk peringatan yang paling terlihat yaitu hujan deras yang menimbulkan adanya genangan air di area lobby kedatangan. Karena kejadian begitu tibatiba dan perusahaan tidak memiliki waktu untuk melakukan perencanaan sehingga pada saat itu PT Angkasa Pura II yang di bantu oleh tim teknis langsung bereaksi untuk mengembalikan air ke posisi yang sebenarnya.

Berdasarkan hasil analisis yang peneliti lakukan dikaitkan dengan teori tahap warning, memang benar bahwa tahap warning merupakan tahap paling penting dalam daur hidup krisis juga sebagai peringatan untuk perusahaan dalam mengenali suatu krisis karena ketika PT Angkasa Pura II tidak langsung bereaksi saat kejadian dapat menyebabkan kerusakan menyeluruh terhadap perusahaan.

Tahap acute crisis adalah tahap krisis mulai terbentuk dan media juga publik mulai mengetahui adanya masalah. Dalam tahap ini, perusahaan tidak dapat berdiam diri karena sudah mulai menimbulkan kerugian. Saat inilah berbagai dokumen dan modul untuk menghadapi krisis harus dikeluarkan dan digunakan. Di saat seperti ini juga dapat diketahui apakah para staf telah dibekali pengetahuan mengenai manajemen krisis atau tidak. Jika tidak, maka sudah terlambat bagi manajemen untuk memulainya dan menyelesaikan masalahnya (Nova, 2009: 96).

Terkait dengan hasil penelitian yang didapatkan dari wawancara dengan $P R$ Manager, PR Senior Officer, dan PR Junior Officer bahwa perusahaan mencoba mengenali permasalahan yang paling mendasar yang menyebabkan munculnya pemberitaan negatif. Setelah mengenali permasalahannya, perusahaan medokumentasikan seluruh pemberitaan yang terdapat di media baik media cetak, media televisi, media online, serta media sosial.

Jika pemberitaan yang beredar tidak sesuai dengan fakta di lapangan perusahaan berhak melakukan klarifikasi yang memanfaatkan sumberdaya perusahaan dan media yang dimiliki perusahaan atau yang disebut kanalkanal korporasi. Hal ini sesuai dengan peran Humas, yang dimana menurut Widodo (2009) yaitu Humas harus bisa memerankan dirinya sebagai penyampai informasi yang memiliki penguasaan atas materi yang disajikan kepada media yang merupakan salah satu stakeholdersnya.

Selanjutnya, upaya Humas dalam melakukan aktivitas media relations menurut 
Anandalina dan Sunarto (2013), sebaiknya Humas dapat memahami dan melayani media, membangun reputasi, menyediakan salinan yang baik, menyediakan sarana verifikasi, dan membangun hubungan personal yang kokoh.

Jika dianalisis, dapat dikatakan bahwa tahap akut yang dilakukan oleh Public relations PT Angkasa Pura II merupakan salah satu cara penanganan yang cepat agar perusahaan tidak mengalami kerugian. Dimana dengan mendokumentasikan pemberitaan di media, memanfaatkan sumber daya perusahaan dan media yang dimiliki perusahaan atau disebut kanal-kanal korporasi sebagai bentuk public relations PT Angkasa Pura II telah dibekali pengetahuan mengenai manajemen krisis.

Menurut Nova (2009: 96) tahap clean-up adalah tahap dimana masalah telah melewati tahap warning tanpa diselesaikan maka kerusakan perusahaan mulai timbul. Inilah waktunya untuk memulihkan perusahaan dari kerugian dan/atau setidaknya menyelamatkan apa saja yang tersisa, baik sisa produk (jika dapat diaplikasikan), reputasi, citra perusahaan, kinerja, dan lini produksi. Saat pemulihan perusahaan harus menghadapi hal-hal yang terkait dengan hukum media, tekanan publik, dan litigasi. Tetapi, hikmah yang dapat diambil, yakni perusahan dapat melihat bagaimana suatu krisis akan timbul, bagaimana menghadapi krisis dan memastikan krisis tidak akan pernah terulang lagi.

Selaras dengan teori tersebut PT Angkasa Pura II di tahap clean-up (pembersihan) yang dilakukan perusahaan yaitu mengapresiasi netizen di media sosial yang telah memberikan masukan ke perusahaan, hal tersebut dilakukan agar citra perusahaan menjadi lebih baik lagi. Selain itu, perusahaan mengeluarkan press release di website perusahaan serta ke media untuk meluruskan pemberitaan negatif yang beredar di masyarakat sekaligus menerangkan kejadian yang sebenarnya.

Jika dianalisis berdasarkan hasil penelitian yang dikaitkan dengan teori bahwa PT Angkasa Pura II telah melewati tahap warning sehingga kerusakan yang timbul pun langsung segera diatasi dengan mengapresiasi netizen di media sosial serta mengeluarkan press release untuk meluruskan pemberitaan negatif.

Tahap Post-crisis adalah tahap yang telah disebutkan sebelumnya, yakni perusahaan seharusnya bereaksi saat suatu krisis muncul ke tahap warning. Jika sejak awal tidak dihentikan, krisis akan terjadi. Jika perusahaan memenangkan kembali kepercayaan publik dan dapat beroperasi kembali dengan normal, maka secara formal dapat dikatakan krisis telah berakhir (Nova, 2009: 97). Jika dihubungkan dengan teori tahap post crisis, memang benar bahwa PT Angkasa Pura II sudah bereaksi di tahap warning dengan langsung menyelesaikan 
permasalahan yang terdapat di Terminal 3 Bandara Internasional Soekarno-Hatta yang dibantu oleh tim teknis. Selanjutnya, pihak perusahaan melakukan kegiatan yang terdapat di event calender mereka yang salah satu kegiatannya adalah Adventure Race to Terminal

3. Di kegiatan ini selain mengembalikan kepercayaan publik juga sebagai kegiatan yang mempromosikan Terminal 3 Bandara Internasional Soekarno-Hatta. Untuk dapat mengidentifikasi suatu krisis, public relations perlu melakukan penelitian. Bila krisis terjadi dengan cepat, maka penelitian harus dilakukan secara informal dan kilat, harus diusahakan kesimpulan atas identifikasi krisis yang terjadi ditarik pada hari yang sama saat data dikumpulkan. Oleh sebab itulah dibutuhkan praktisi humas yang cakap dan peka dalam mengumpulkan data yang diperlukan (Kasali, 2000: 232).

Terkait dengan teori identifikasi krisis diatas maka memang benar, public relations $\mathrm{PT}$ Angkasa Pura II telah melakukan identifikasi terhadap suatu krisis. Terbukti dari hasil penelitian, langkah awal yang dilakukan perusahaan yakni mencari tahu tipe krisis termasuk tipe krisis kecil, sedang atau tinggi. Adapun tipe krisis saat kejadian termasuk ke dalam tipe krisis sedang atau menengah. Dikatakan tipe krisis sedang atau menengah karena saat kejadian tidak sampai mengancam nyawa atau menghilangkan nyawa para penumpang pengguna jasa bandara. Langkah selanjutnya yang dilakukan pihak perusahaan yaitu mempunyai standby statement hal ini diperlukan perusahaan ketika perusahaan disuguhi banyak pertanyaan dari media maupun masyarakat, sehingga dengan adanya standby statement perusahaan dapat dengan cepat menjawab pertanyaan kemudian dari jawaban itu dirangkum yang dibuat ke dalam bentuk press release. Kemudian dari hasil penelitian juga, public relations PT Angkasa Pura II mengaktifkan tim krisis yang kalau dianalisis dapat dikatakan bahwa dengan adanya tim krisis mendukung kegiatan para karyawan di perusahaan selama masa krisis terjadi

Menurut Ruslan (2007: 76) analisa krisis merupakan langkah pengembangan dengan menggunakan formula $5 \mathrm{~W}+1 \mathrm{H}$ untuk mengungkapkan dan menganalisis secara mendalam sistematis, informatif dan deskriptif krisis yang terjadi melalui suatu laporan yang mendalam (in-depth reporting). Pada saat praktisi atau masa akut krisis, bisa dianalisis melalui beberapa pertanyaan yang diajukan untuk menetapkan penanggulangan suatu krisis.

Mengacu pada pengertian tersebut, hasil penelitian di atas didapatkan bahwa PT Angkasa Pura II melakukan analisis data yang diperoleh di lapangan dengan cara menyiapkan standby statement, standby statement merupakan 
sebuah rangkaian statement-statement yang sudah dipersiapkan perusahaan, press release, dan press conference yang kemudian segala informasi dan fakta di lapangan tersebut disampaikan kepada masyarakat atau penumpang pengguna jasa bandara melalui media. Selain itu, public relations PT Angkasa Pura II juga harus selalu update informasi ke media baik secara formal maupun informal agar informasi antara perusahaan dengan media berkesinambungan dalam artian jika perusahaan diberitakan kurang baik atau negatif media dapat memberikan informasi bahwa perusahaan telah melakukan sesuatu serta memberikan solusi dari krisis yang terjadi. Krisis layaknya seperti penyakit dan untuk mencegah krisis menyebar luas maka krisis harus diisolasi, dikarantinakan sebelum tindakan serius dilakukan (Kasali, 2000: 232).

Sehubungan dengan hasil penelitian, langkah isolasi krisis yang dilakukan public relations PT Angkasa Pura II untuk mencegah krisis menyebar luas yaitu dengan langsung bekerjasama dengan tim teknis untuk mengeringkan lokasi yang disebabakan oleh genangan air. Setelah proses pengeringan, perusahaan memberitahu kepada media bahwa masalah sudah dapat teratasi. Selain itu, dari hasil penelitian yang disesuaikan dengan teori pihak perusahaan juga melakukan kerjasama dengan media agar ketika terjadi krisis di perusahaan, perusahaan langsung dapat menginformasikan kepada media untuk menahan para reporternya agar tidak memberitakan krisis tersebut terus menerus.

Jika dianalisis, dapat dikatakan bahwa public relations PT Angkasa Pura II melakukan kerja sama dengan tim teknis bandara juga media adalah salah satu bentuk isolasi krisis. Dalam langkah pengendalian krisis, perusahaan perlu melakukan penetapan strategi yang akan diambil. Tiga strategi pengendalian krisis menurut Kasali (2000: 232-233) diantaranya: (1) Strategi Defensif, (2) Strategi Adaptif, dan (3) Strategi Dinamis.

Sejalan dengan teori tersebut PT Angkasa Pura II mengambil langkah strategi seperti memberikan update informasi ke masyarakat seperti kegiatan yang telah dilakukan selama menangani krisis kemudian perusahaan mengeluarkan press release untuk menimbulkan citra positif. Selain itu, perusahaan dibantu konsultan untuk meredam pemberitaan negatif dan menggantikannya menjadi pemberitaan yang bersifat positif berguna dalam meluruskan citra perusahaan.

Pihak public relations PT Angkasa Pura II mengambil strategi adaptif yang langkah langkahnya mencakup hal-hal: (1) mengubah kebijakan, (2) modifikasi operasional, (3) kompromi, (4) meluruskan citra. Dan yang salah satu diterapkan PR PT Angkasa Pura II adalah 
meluruskan citra dengan cara mengeluarkan press release serta dibantu konsultan untuk meredam pemberitaan negatif.

Menurut Ruslan (2007: 76-78) dalam langkah program pengendalian perusahaan telah mempunyai strategi umum sebelum krisis muncul dan melakukan evaluasi krisis yang terjadi. Tujuannya adalah untuk melihat sejauh mana perkembangan krisis itu di dalam masyarakat.

Jika dikaitkan dengan hasil penelitian peneliti dengan para informan bahwa program pengendalian yang dilakukan melalui proses evaluasi oleh PT Angkasa Pura II yaitu dengan meningkatkan kesiapan dalam menghadapi krisis kapanpun krisis itu terjadi kemudian perusahaan lebih aktif lagi menggunakan monitoring tools untuk melihat tonetone pemberitaan, selanjutnya perusahaan menjadikan krisis yang belum pernah terjadi sebelumnya dalam lampiran baru atau krisis baru yang nantinya dapat menjadi pedoman crisis communication untuk anggota public relations perusahaan.

Jika dianalisis, dapat dikatakan bahwa program pengendalian yang dilakukan oleh PT Angkasa Pura II merupakan salah satu bentuk strategi umum yang dimiliki perusahaan sebelum krisis muncul. Dimana dengan melakukan evaluasi terhadap suatu krisis berarti perusahaan telah bertanggung jawab terhadap stakeholdernya dan untuk melihat sejauh mana perkembangan krisis itu di masyarakat.

\section{SIMPULAN}

Simpulan yang diperoleh peneliti setelah melakukan penelitian ini yaitu aktivitas public relations yang dilakukan oleh PT Angkasa Pura II dalam menangani pemberitaan negatif pada awal pembukaan Terminal 3 Bandara Internasional Soekarno - Hatta yaitu tahapan yang dilakukan Public relations PT Angkasa Pura II dalam menangani krisis adalah (a) tahap pre-crisis PT Angkasa Pura II melakukan press conference bersama Garuda Indonesia untuk membahas operasional sekaligus melakukan simulasi pengoperasian Terminal 3 Bandara Internasional Soekarno-Hatta. (b) tahap warning, bentuk peringatan yang terlihat yaitu hujan deras yang menimbulkan adanya genangan air di area lobby kedatangan. (c) tahap acute crisis, perusahaan mengenali permasalahan yang paling mendasar yang menyebabkan munculnya pemberitaan negatif. Setelah mengenali permasalahannya perusahaan mendokumentasikan seluruh pemberitaan yang terdapat di media baik media cetak, media televisi, media online, serta media sosial. Perusahaan melakukan klarifikasi terhadap pemberitaan yang tidak tepat dengan memanfaatkan sumber daya perusahaan dan media yang dimiliki perusahaan atau disebut 
kanal-kanal korporasi. (d) tahap clean up, perusahaan melakukan pembersihan dengan mengapresiasi netizen di media sosial yang telah memberikan masukan ke perusahaan, hal tersebut dilakukan agar citra perusahaan menjadi lebih baik lagi. Kemudian mengeluarkan press release di website perusahaan serta ke media untuk memberikan informasi terkait kejadian di Terminal 3 Bandara Internasional SoekarnoHatta. (e) tahap post-crisis, perusahaan melaksanakan kegiatan yang terdapat di event calender yang bekerja sama dengan unit-unit di Terminal 3 Bandara Internasional SoekarnoHatta salah satunya adalah Adventure Race to Terminal 3 kemudian perusahaan melakukan media monitoring, memunculkan press release terkait prestasi perusahaan. Selain itu, publik figur memposting kembali mengenai sarana di Terminal 3 yang pernah dikritik olehnya.

Selain itu upaya mengelola krisis yang dilakukan Public relations PT Angkasa Pura II dalam menangani krisis adalah (a) identifikasi krisis, perusahaan berkoordinasi dengan Senior Manager Terminal 3 kemudian menentukan tipe atau kategori krisis yang dihadapi. (b) analisa krisis, perusahaan melakukan analisis data yang diperoleh dengan cara menyiapkan standby statement. Standby statement merupakan sebuah rangkaian statemen-statement yang sudah dipersiapkan perusahaan, mengaktifkan tim krisis, press release, dan press conference yang kemudian segala informasi dan fakta di lapangan tersebut disampaikan kepada masyarakat atau penumpang pengguna jasa bandara melalui media. (c) isolasi krisis, perusahaan bekerjasama dengan tim teknis untuk mengeringkan lokasi yang disebabkan oleh genangan air. Setelah proses pengeringan, perusahaan memberitahu kepada media bahwa masalah sudah teratasi. Selain itu, pihak perusahaan juga melakukan kerja sama dengan media agar ketika terjadi krisis di perusahaan, perusahaan langsung dapat menginformasikan kepada media untuk menahan para reporternya agar tidak memberitakan krisis tersebut terus menerus. (d) pilihan strategi, perusahaan melakukan strategi dengan memperbarui informasi ke masyarakat seperti kegiatan yang telah dilakukan selama menangani krisis kemudian perusahaan mengeluarkan press release untuk menimbulkan citra positif. Selain itu, perusahaan dibantu oleh konsultan untuk meredam pemberitaan negatif dimana konsultan tersebut dapat mengubah pemberitaan negatif menjadi positif yang berguna meluruskan citra perusahaan. (e) program pengendalian, yang dilakukan melalui proses evaluasi oleh PT Angkasa Pura II (Persero) dengan meningkatkan kesiapan dalam menghadapi krisis yang terjadi dan selanjutnya perusahaan lebih aktif lagi menggunakan monitoring tools untuk melihat tone-tone pemberitaan, selanjutnya perusahaan 
menjadikan krisis yang belum pernah terjadi sebelumnya dalam lampiran baru atau krisis baru yang nantinya dapat menjadi pedoman crisis communication untuk anggota public relations perusahaan.

Adapun saran dari penelitian yang dilakukan oleh peneliti bagi kalangan akademis dan kalangan praktisi, yaitu sebagai berikut:

Berdasarkan hasil penelitian ini, peneliti merekomendasikan kepada akademisi atau peneliti selanjutnya yang akan membahas mengenai aktivitas public relations untuk meninjau dan meneliti kasus-kasus terbaru dan dengan ruang lingkup krisis yang berbeda. Pada setiap tahun biasanya akan timbul krisis-krisis baru yang bisa menimpa perusahaan besar di Indonesia, untuk itu disarankan kepada peneliti berikutnya untuk meneliti dan melalukan perbandingan terhadap peran praktisi PR pada perusahaan tersebut dalam menghadapi krisis yang dialami. Juga menarik untuk membandingkan pendekatan media relations yang dilakukan masing-masing perusahaan besar di Indonesia pada saat menghadapi sebuah krisis.

Berdasarkan hasil penelitian ini, peneliti merekomendasikan kepada praktisi public relations untuk lebih bersiap diri dalam menangani krisis. Salah satu bentuk kesiapan praktisi PR untuk menghadapi sebuah potensi krisis adalah dengan selalu waspada dan memperhatikan reaksi masyarakat pada media sosial (netizen). Reaksi yang cepat dan tepat akan dapat membatasi dampak negatif dari krisis yang dihadapi (damage limitation). Seperti yang didapati pada penelitian ini, perusahaan yang diteliti memperlihatkan kesiapan mereka dalam memberikan respon terhadap adanya keluhan pengunjung terhadap fasilitas yang disediakan perusahaan. Respons yang dilakukan pada media sosial oleh perusahaan ini dinilai cepat dan tepat sehingga dapat membatasi dampak buruk terhadap citra perusahaan.

\section{DAFTAR PUSTAKA}

Anandalina, C. G. \& Sunarto. (2013). Aktivitas public relations pt. agung podomoro land, tbk, dalam menjalankan media relations untuk meningkatkan publisitas. Jurnal Komunikasi Universitas Tarumanagara, Vol. 5, No. 1, 77-86.

Biro Komunikasi dan Informasi Publik. (2016). Belum penuhi standar, pengoperasian terminal 3 ultimate ditunda. Diakses dari http: //www.dephub.go.id/welcome/ readPost/belum-penuhi-standar,pengoperasian-terminal-3-ultimateditunda. Pada tanggal 8 September 2016, 13: 17 WIB.

Bungin, B. (2013). Penelitian kualitatif komunikasi, ekonomi, kebijakan publik dan ilmu sosial lainnya. Jakarta: Kencana.

Creswell, J. W. (2014). Penelitian kualitatif \& desain riset: memilih di antara lima pendekatan. Yogyakarta: Pustaka Pelajar.

Iqbal, F. (2014). Komunikasi dalam adaptasi budaya. Jurnal Komunikasi Profektif. Vol. 
7, No. 2, 65-76.

Jefkins, F. (2004). Public relations. Jakarta: Erlangga.

Kasali, R. (2000). Manajemen public relations: konsep dan aplikasinya di indonesia. Jakarta: Pustaka Utama Grafiti.

Mukhtar. (2013). Metode penelitian deskriftif kualitatif. Jakarta: GP Press Group.

Nova, F. (2009). Crisis public relations: strategi pr menghadapi krisis, mengelola isu, membangun citra dan reputasi perusahaan. Jakarta: Gramedia Widiasarana Indonesia.

Ruslan, R. (2007). Manajemen public relations dan media komunikasi: konsepsi dan aplikasi (edisi revisi). Jakarta: Rajawali Pers.

Suherli, U. R. (2015). Peran humas dalam mengelola konflik. Jurnal Komunikasi Profektif. Vol. 8, No. 1, 79-91.

Sugiyono. (2013). Metode penelitian kuantitatif, kualitatif dan $r \& d$. Bandung: Alfabeta.

Widodo, H. B. (2009). Peran humas pemerintah daerah dalam kasus penambangan pasir besi di kabupaten kulon progo. Jurnal Ilmu Komunikasi. Vol. 7, No. 2, 189-197.

Yogi, G. P. (2016). Emergency response plan garuda indonesia. Jurnal PRofesi Humas. Vol. 1 No. 1, 65-77. 